\title{
Online Class Adaptation of Graduate and Post Graduate Students During the Covid-19 Pandemic in Bangladesh
}

\author{
Sanjida Islam $^{1} \quad$ Israt Moriom Khan $^{2 *} \quad$ Sabrina Quadir ${ }^{2}$ \\ 1.Lecturer, Department of Business Administration, Daffodil Institute of IT, Dhaka, Bangladesh \\ 2.Senior Lecturer, Department of Business Administration, Daffodil Institute of IT, Dhaka, Bangladesh
}

\begin{abstract}
Online class is defined as a mode of class conducted using electronic devices through the internet. There are various obstacles to adapting online classes smoothly. The objective of the study was to evaluate the adaptation of online classes of graduate and postgraduate students and to scrutinize the barriers and benefits of it. There are both primary and secondary data used in this study. The research was conducted from January - May of 2021 surveying a questionnaire of 890 samples. Some simple statistical tools; pie-chart, bar diagram and tables were used to analyze data and present the result. The findings showed poor connection; poor motivation; unreliable technology; limited timeframe of class; inappropriate support; and minimal course design were the limitations of online class and had limited benefits. The government and institutional authorities should take academic decisions focusing on the barriers.
\end{abstract}

Keywords: Online Class, Covid-19 Pandemic, Online Platform, Barriers, Bangladesh

DOI: $10.7176 / \mathrm{EJBM} / 13-16-05$

Publication date:August $31^{\text {st }} 2021$

\section{Introduction}

Online class the system of class conducted over the internet where students use their home computers or other devices through the internet. In the last 20 years, the use of the Internet has greatly expanded and it has transformed the way people communicate and think about knowledge and learning. Online class has switched the face of traditional classrooms and created education more available than ever before. It has become more effective during the crisis period of the Covid-19 pandemic and now is playing a vital role to keep the education system sustainable.

With the expansion of globalization, the world has become smaller just like a global village. As a result, the countries all over the world have become interrelated with each other and the people are experiencing many common crises worldwide like Covid-19. At present, Covid-19 which takes its presence as pandemic roaming around the world is highly contagious. The WHO has suggested that people must maintain the social distance (e.g., at least 3 feet between and among people, avoiding crowd and public gathering) to restrain the disease for its highly contagious characteristic. (World Health Organization, 2020a). According to the recommendation of health experts, the Government of Bangladesh implemented a lockdown to control the infection of the virus among people on 17th March, 2020 (Hasan et al, 2020). There has been an educational gap for the shutting down of the educational institutions to control the widespread infection of coronavirus. The government of Bangladesh has taken the step to inaugurate the online class system to engage the students as the reopening of educational institutions was not certain from the imposing of the lockdown. Many countries all over the world have taken initiatives to practice the online education process to reduce this educational gap during the Covid-19 pandemic (Rahman, 2020). Now, an online class or online education system is the best potential option for face to face learning. Most of the educational institutions all over the world are maintaining communication with the students through technical platforms like Facebook, Zoom, Google classroom, Google meet etc. (Fami, 2020). The UGC( University Grants Commission) declared observing the hamper of academic progress that the universities can run their academic activities through online platforms like Zoom, Google Meet, etc. Getting the support from BdREN most of the public and private universities in Bangladesh are now conducting the classes using online platforms (Rahman et al, 2020).

It is not an easy task from the perspective of a third world country like ours to practice the online teaching and learning systems not only for the teachers but also for the students. In Bangladesh, most of the educational institutions have limited use and are not habituated with the digital platforms for academic purposes. The rural areas and some destitute urban areas are experiencing many problems and limitations to adopt the online process (Fami, 2020). There are many obstacles like; distance issues, limited technical support, lack of internet access and lack of financial solvency observed by both the students and the teachers. This Covid-19 pandemic has a great impact on every basic factor around the world, even on education and mostly on students and their adaptation of online classes which is one of the great challenges to meet. This paper focuses on online class adaptation of graduate and post graduate students during the covid-19 pandemic in Bangladesh. 


\section{Literature review:}

Now-a-days online class is a very familiar term to the students as an outcome of Covid-19. Online classes totally depend on technology. There are many studies during the Covid-19 which are related to the impacts of Covid-19 on all basic factors including educational factors around the world. Ahmed et al., (2020a); Anwar et al., (2020); Chen and Yuan, (2020); Satici et al., (2020) revealed that countries all over the world have taken various steps like closing educational and administrative or other institutions, and other public places including markets, shopping malls, and transportation to avoid public gathering.

During the Covid 19 pandemic, the use of technology has created a new dimension in learning and teaching worldwide, decreasing the short-term crisis which hampers the traditional learning process. In spite of its various advantages, it is a challenging task to hold on to students on online platforms. Butler and Sellbom (2002) and Rogers' diffusion theory (2003), said that there are many barriers which are preventing individuals, groups or institutions from adopting technology. William Massy and Robert Zemsky (1995), analyzed that higher education will not be more fruitful until colleges and universities adopt technological applications for the purposes of teaching and learning. The progress and the utilization of online technology in teaching and learning have been possible only with the blessings of the expansion of computer technology.

Zaman, (2020) showed in his study that during the corona pandemic, the students in graduate and postgraduate level in Bangladesh are facing different problems which are the barriers for online classes, such as the constraint of resources, unaffordability of devices, low-speed internet connections, economic insolvency and matter of distance. Majed et al., (2020); Sarker et al., (2019); Zaman, 2020) depicted the scenario of Bangladesh that unsteady internet connection is a major obstacle for continuing online class smoothly. LightCastle Partners (2020) said that the unexpected growth of users and the demand of high-speed internet are hindering the server as well.

Moreover, Majed et al., (2020) has explained in his study that in Bangladesh, another major problem faced by the students of public universities is to attend the online classes for economic insolvency or for not affording an upgraded desktop or laptop. (Majed et al., (2020); Zaman, (2020) have described in their studies that there are about $36.7 \%$ families which have the ability to use the internet in Bangladesh where only $5.6 \%$ can afford to use computer facilities. Besides, Lassoued et al., (2020), also has revealed that both teachers and students become demoralized towards online classes for not having proper guidance about 'how to conduct and evaluate the online classes' for the laboratory-oriented subjects.

\section{Objectives of the study:}

The study was conducted all over the country, Bangladesh, with one objective after another:

I. To evaluate the adaptation of online classes of graduate and postgraduate students;

II. To scrutinize the barriers and benefits of online classes noted by graduate and postgraduate students.

\section{Methodology of the study:}

Both primary and secondary information are analyzed in this study. Due to the lack of adequate published studies about the online classes, most of the studies have been based on preliminary data. A well-structured questionnaire was designed which contained some information about online classes, demographic coverage, their experience, barriers, advantages and challenges. Questionnaire link was sent to respondents using 'Google form' through Email, Whatsapp and Facebook messenger. A total of 890 participants send complete information regarding this survey. Some simple statistical tools such as pie-chart, bar diagram and some tables have been used to analyze and present the result of collected data.

Table-1: Respondents selection

\begin{tabular}{|c|c|c|}
\hline Study Area & Types of Educational Institutions & Number of University \\
\hline Dhaka & Public University & 2 \\
\hline Dhaka & Private University & 14 \\
\hline Dhaka & Private Institution (Under National University) & 2 \\
\hline Dhaka & Non-Government Graduate College & 1 \\
\hline Savar & Public University & 1 \\
\hline Sylhet & Public University & 1 \\
\hline Gopalganj & Public University & 1 \\
\hline
\end{tabular}




\begin{tabular}{|c|c|c|}
\hline Study Area & Types of Educational Institutions & Number of University \\
\hline Mymensingh & Public University & 1 \\
\hline & Total & 23 \\
\hline
\end{tabular}

\section{Source: Field survey}

Bangladesh is a growing country with a significant expansion and demand in its education sector. Since 2007, university enrollment has grown to more than 3.3 million. There are now 135 universities (40 public universities and 95 private universities) in Bangladesh where 28568 teachers have been recruited and 856726 students have studied there.

\section{Results and Discussions:}

\subsection{Gender:}

Students are the most emerging assets of our nation. In the context of our population, half are male and half are female. So both men and women have an equal contribution to make in the development of our country and society as a whole. Out of 890 respondents, 617 were male participants which was $69.3 \%$; 263 participants were female which was $29.5 \%$; and 10 participants refused to disclose gender which is $1.1 \%$.

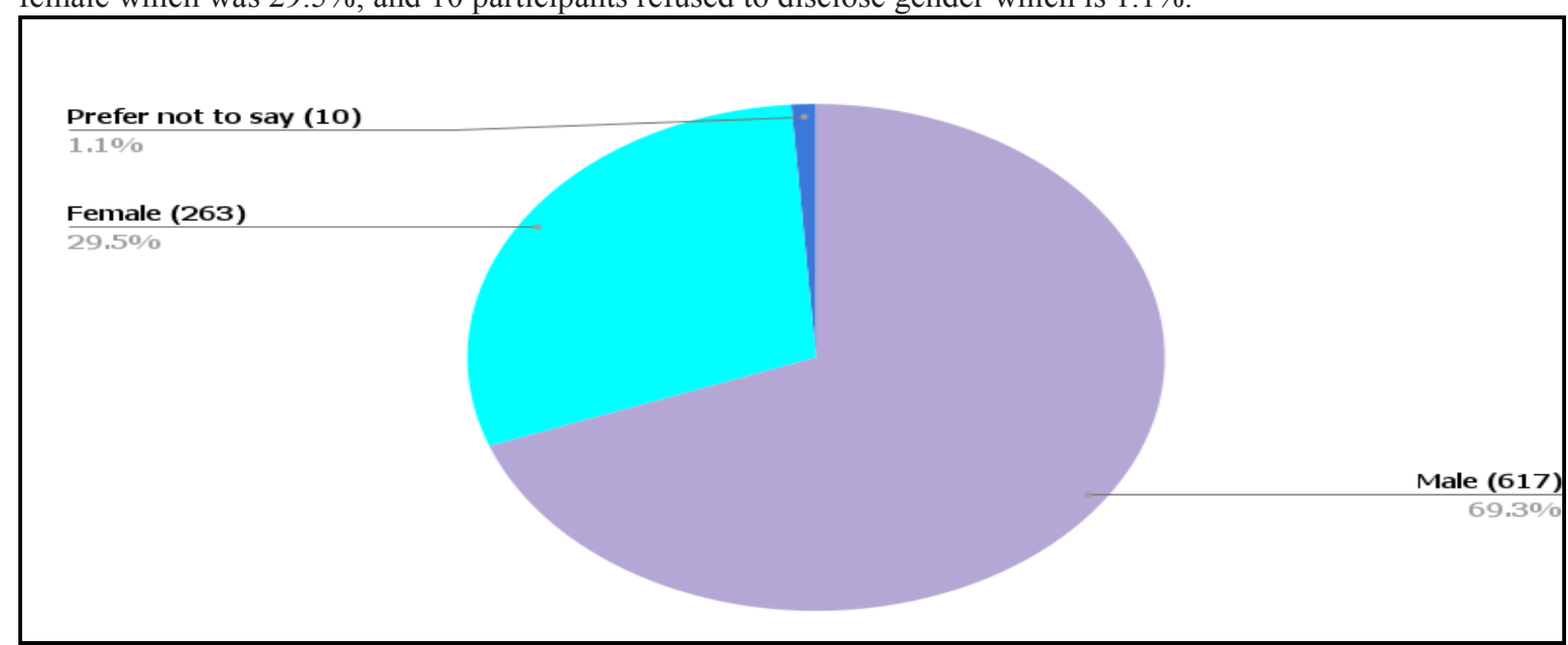

Figure-1: Gender of respondents

\subsection{Age:}

Figure- 2 shows that the range of respondents is 18 to 26 . Among all the respondents, most are in the age group of 20-23 years. There are 760 students in this main range which is $85.4 \%$. Among them, most of the respondents are 21 years old.

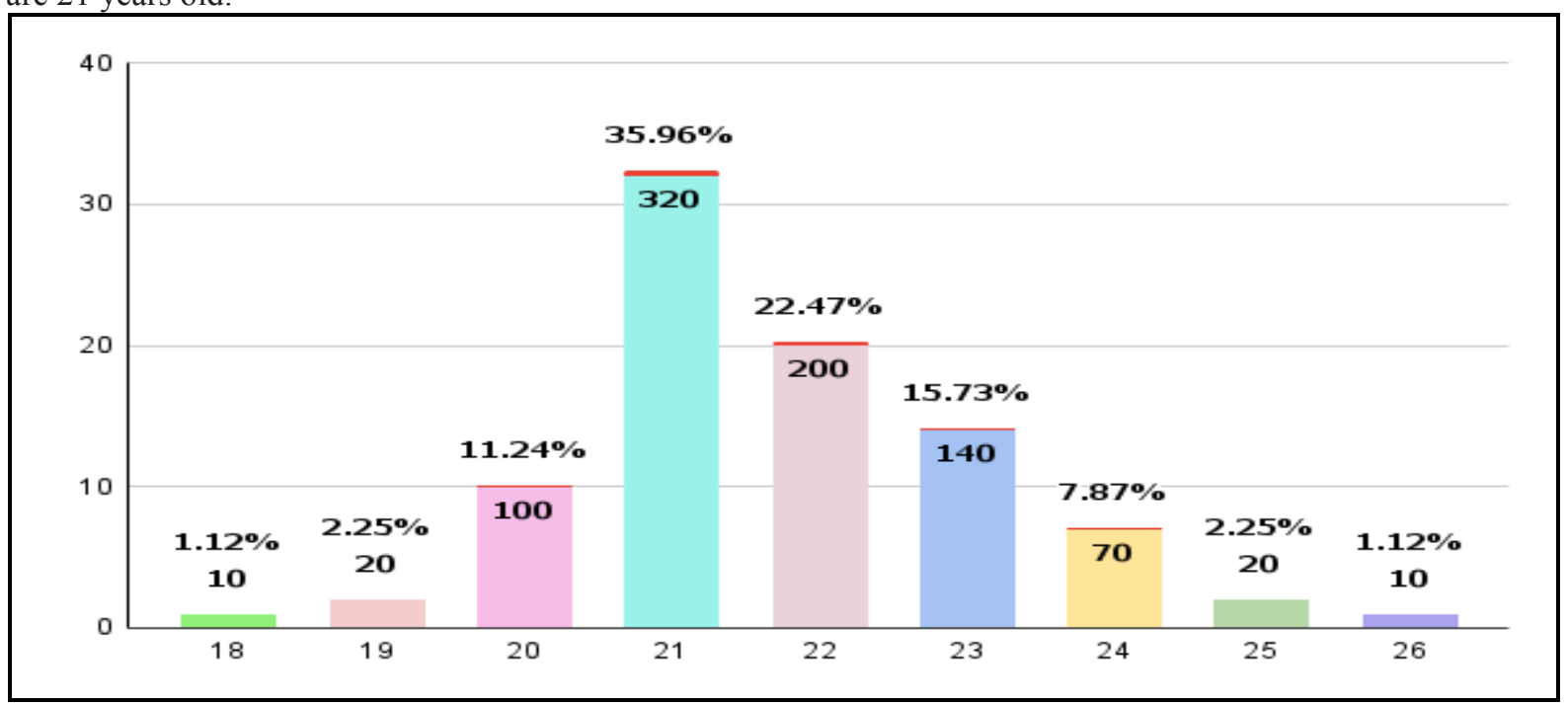

Figure-2: Age of respondents 


\subsection{Name of institutions:}

The coverage of research areas is spread all over the country. We are covering 23 educational institutions including public universities, private universities, private institutions and non-government graduate colleges. There are 4 public universities outside the capital, 14 private universities, 2 public universities, 2 private institutions (under national university) and 1 non-government graduate college inside the capital.

Table-2: Name of institutions

\begin{tabular}{|c|c|c|c|}
\hline SI No. & Name of University & $\begin{array}{l}\text { No of } \\
\text { Students }\end{array}$ & Percentage \\
\hline 1. & Dhaka University & 30 & $3.37 \%$ \\
\hline 2. & Shahjalal University of Science \& Technology & 10 & $1.12 \%$ \\
\hline 3. & Daffodil International University & 90 & $10.11 \%$ \\
\hline 4. & MIST & 70 & $7.87 \%$ \\
\hline 5. & BRAC International University & 100 & $11.24 \%$ \\
\hline 6. & Manarat International University & 80 & $8.98 \%$ \\
\hline 7. & BUET & 70 & $7.87 \%$ \\
\hline 8 & DIIT & 100 & $11.24 \%$ \\
\hline 9. & CIBT & 10 & $1.12 \%$ \\
\hline 10. & Ahsanullah University of Science and Technology & 30 & $3.37 \%$ \\
\hline 11. & $\begin{array}{l}\text { Bangabandhu Sheikh Mujibur Rahman Science and Technology } \\
\text { University }\end{array}$ & 100 & $11.24 \%$ \\
\hline 12. & Bangladesh Agricultural University & 10 & $1.12 \%$ \\
\hline 13. & UODA & 10 & $1.12 \%$ \\
\hline 14. & AIUB & 10 & $1.12 \%$ \\
\hline 15. & Jahangirnagar University & 10 & $1.12 \%$ \\
\hline 16. & Mirpur college & 10 & $1.12 \%$ \\
\hline 17. & BUFT & 10 & $1.12 \%$ \\
\hline 18. & Green University & 10 & $1.12 \%$ \\
\hline 19. & University of Asia Pacific & 70 & $7.87 \%$ \\
\hline 20. & East West University & 10 & $1.12 \%$ \\
\hline 21. & State University & 20 & $2.25 \%$ \\
\hline 22. & UITS & 20 & $2.25 \%$ \\
\hline 23. & Bangladesh University of Business and Technology & 10 & $1.12 \%$ \\
\hline
\end{tabular}



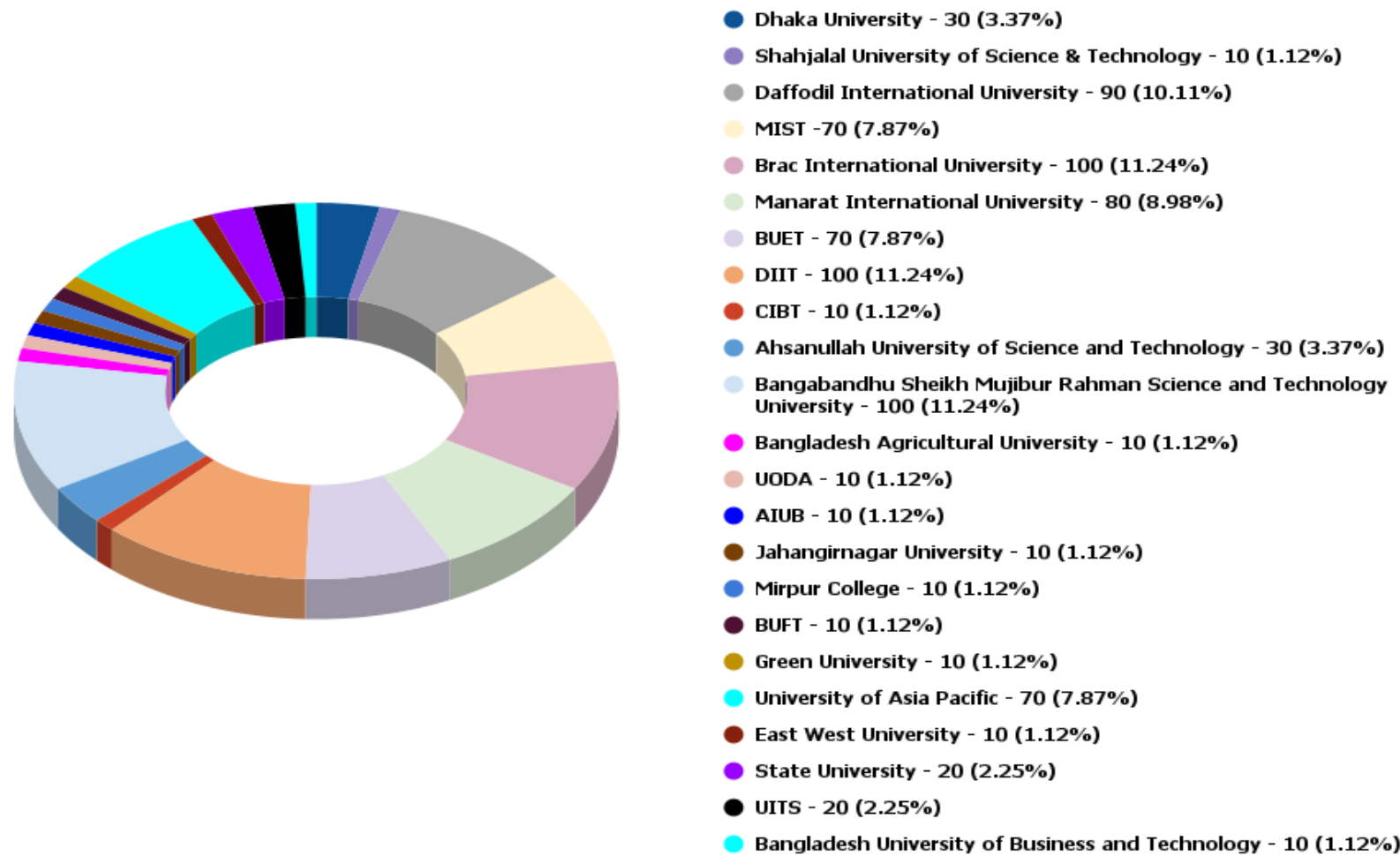

Figure-3: Name of institutions

\subsection{Educational level:}

In this study, we have focused on higher education students (undergraduate and postgraduate level students). Out of 890 respondents, 750 students are studying at undergraduate level which is $84.27 \%$ and 140 students are studying at postgraduate level which is $15.73 \%$ in different universities.

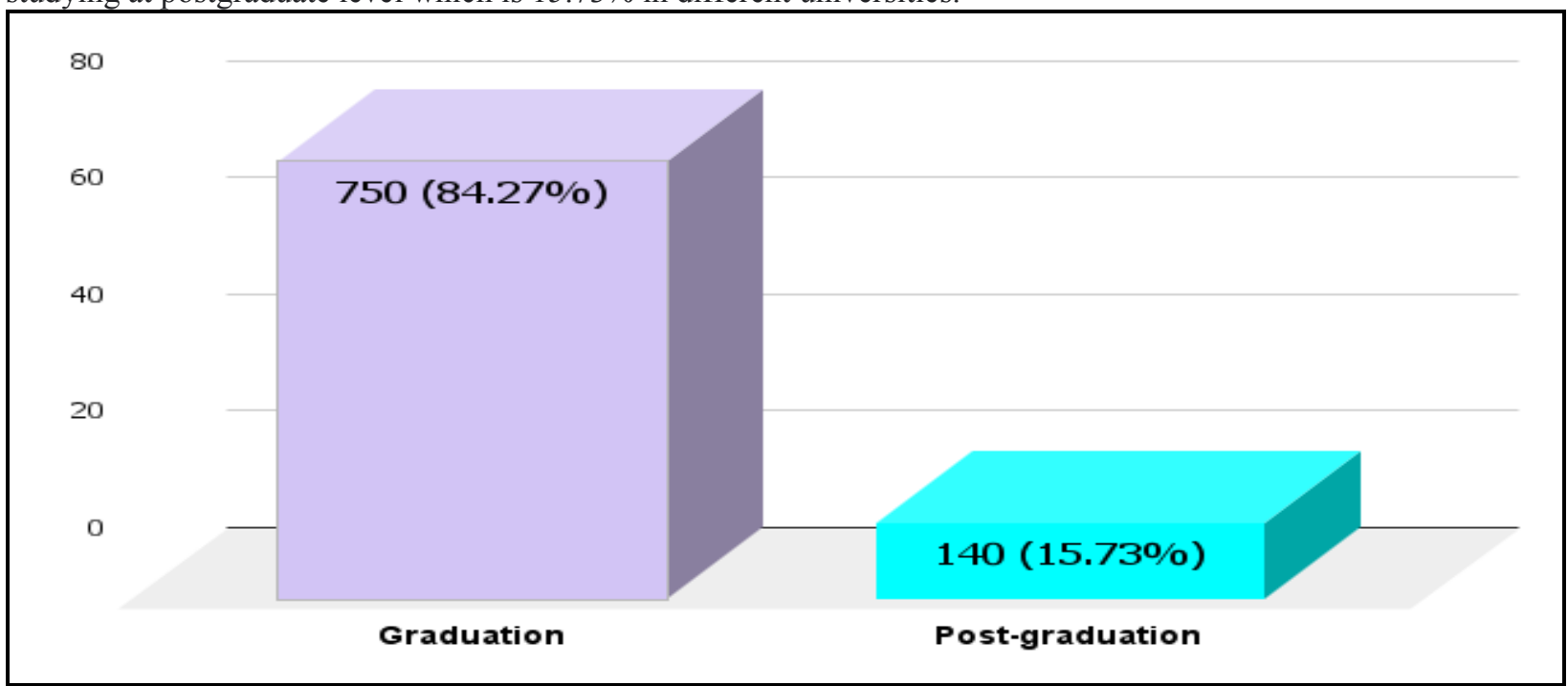

Figure-4: Education level

\subsection{Coverage of area:}

Our students are taking part in their academic courses from their own homes during the corona epidemic. Our survey found that 660 students from urban areas are taking part in online classes and 230 students are from rural areas. 


\section{Urban (660)}

$74.2 \%$

\section{Figure-5: Coverage of area}

\subsection{Connection to be used for online class:}

For participating in online classes, it is necessary for students to have broadband connection or mobile data. In this study we found that among 890 students, 270 students participated in online classes using mobile data and 620 students participated using Wi-Fi or broadband connection.

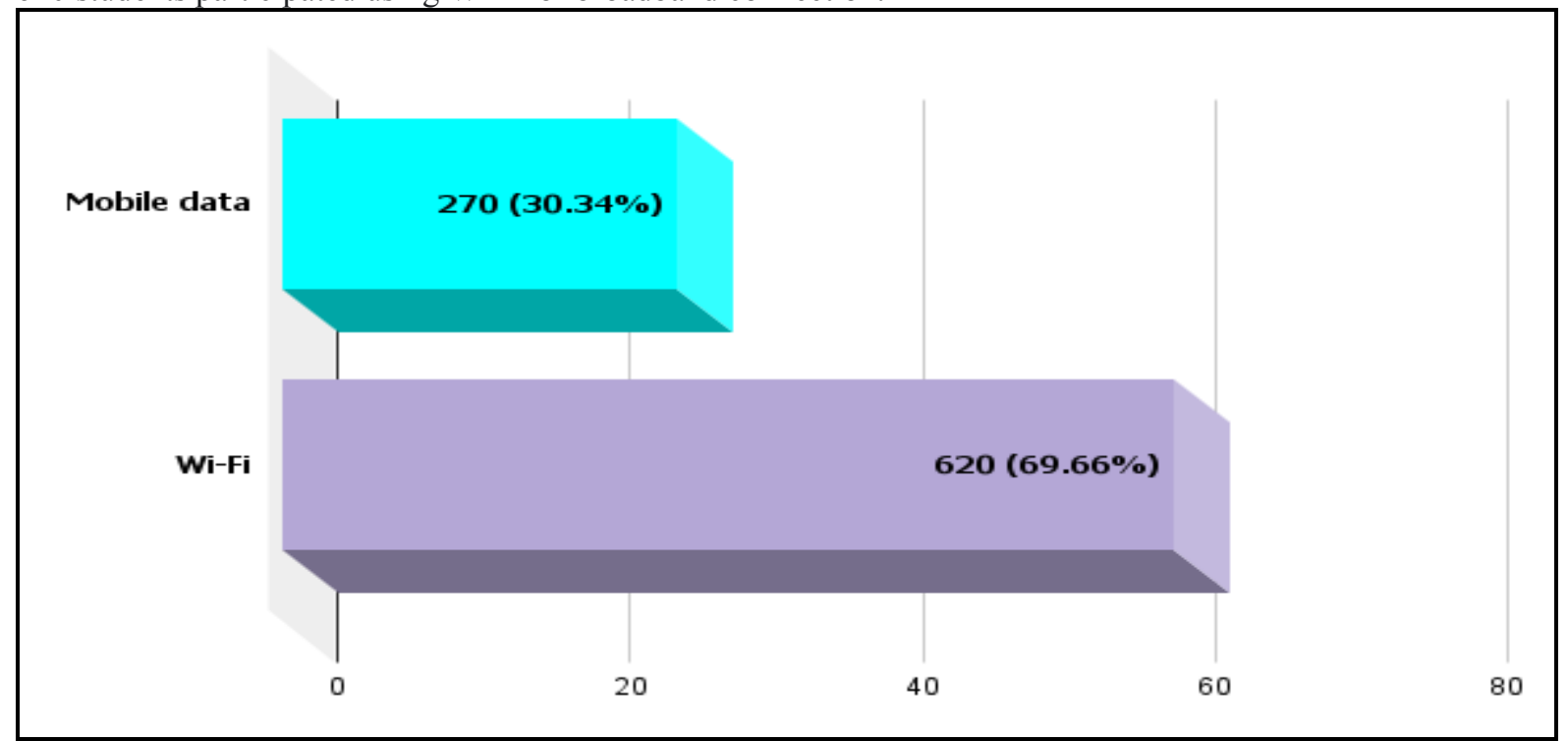

Figure-6: Connection to be used for online class

5.7 Device to be used for online class:

Students need to use some devices such as smartphones, notebooks, laptops or desktops to take part in online classes. In this survey we found that most students have used smartphones. Only $7.86 \%$ of students used desktop; $11.24 \%$ of students used laptops; and $80.9 \%$ of students used smartphones. 


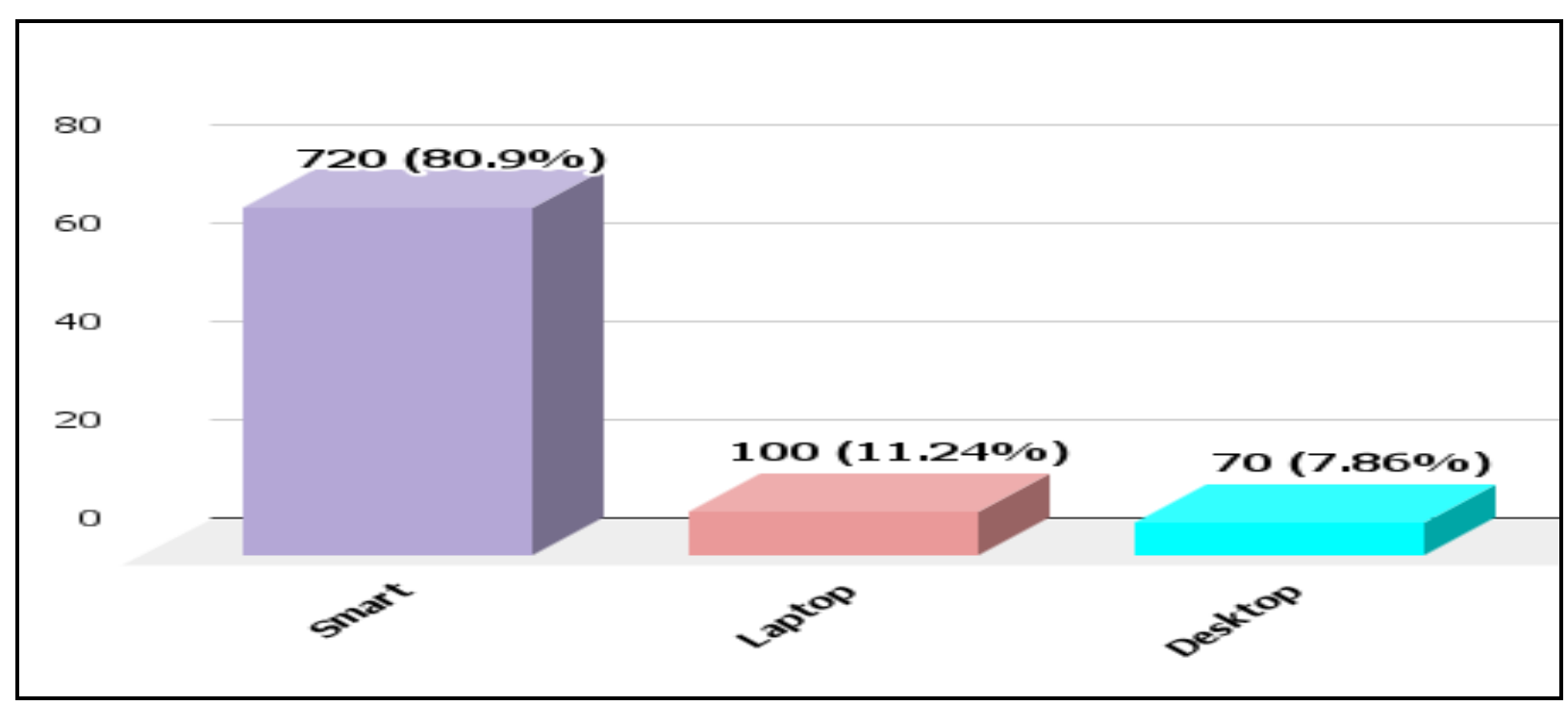

Figure-7: Devices to be used for online class

\subsection{Platform to be used for conducting online class:}

The virtual classroom is used by educational institutions to conduct classes remotely in order to maintain the functionality available in the traditional classroom environment. There are several virtual platforms for students to take part in online classes like Zoom, Webex Meeting, Adobe Connection, Schoology, Blackboard, Tovuti LMS, Panopto, Top Hat. However, considering the context of Bangladesh, Zoom, Google Meet, Big Blue Button, etc.are the most used and familiar platforms for conducting online classes especially for our graduate and postgraduate students. In this survey, we found that Google meet was the most used platform. Out of 890 students, $52.81 \%$ of students using google meet, $43.82 \%$ of students using the zoom platform to participate in online class whereas $3.37 \%$ of students used various virtual classroom software.

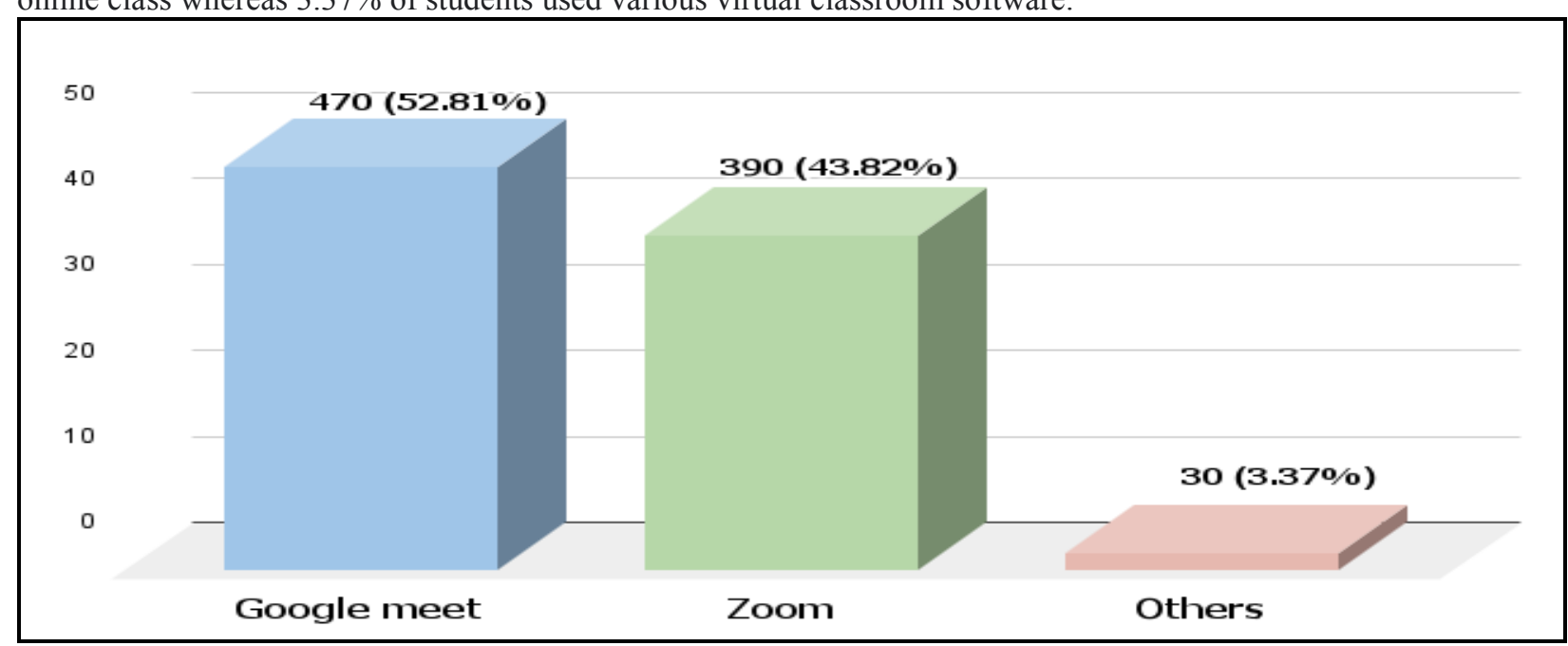

Figure-8: Platform to be used for conducting online class

\subsection{Opinion about adaptation of online class:}

The most challenging aspect for students in this pandemic was to switch for online classes. For that reason $55.7 \%$ of the students have faced difficulties to adopt or switch into online classes and $44.3 \%$ of the students have found it easy. 
No (500)

$55.7 \%$

Figure-9: Opinion about adaptation of online class

\subsection{Opinion about innovativeness and attractiveness of online class:}

In the virtual platform, the interaction between teacher and students is much less than the traditional one and sometimes students find them isolated and demotivated. In this study, we have found that only $18.2 \%$ of students have found online classes to be innovative \& attractive and the majority of them $81.8 \%$ did not find it innovative $\&$ attractive.

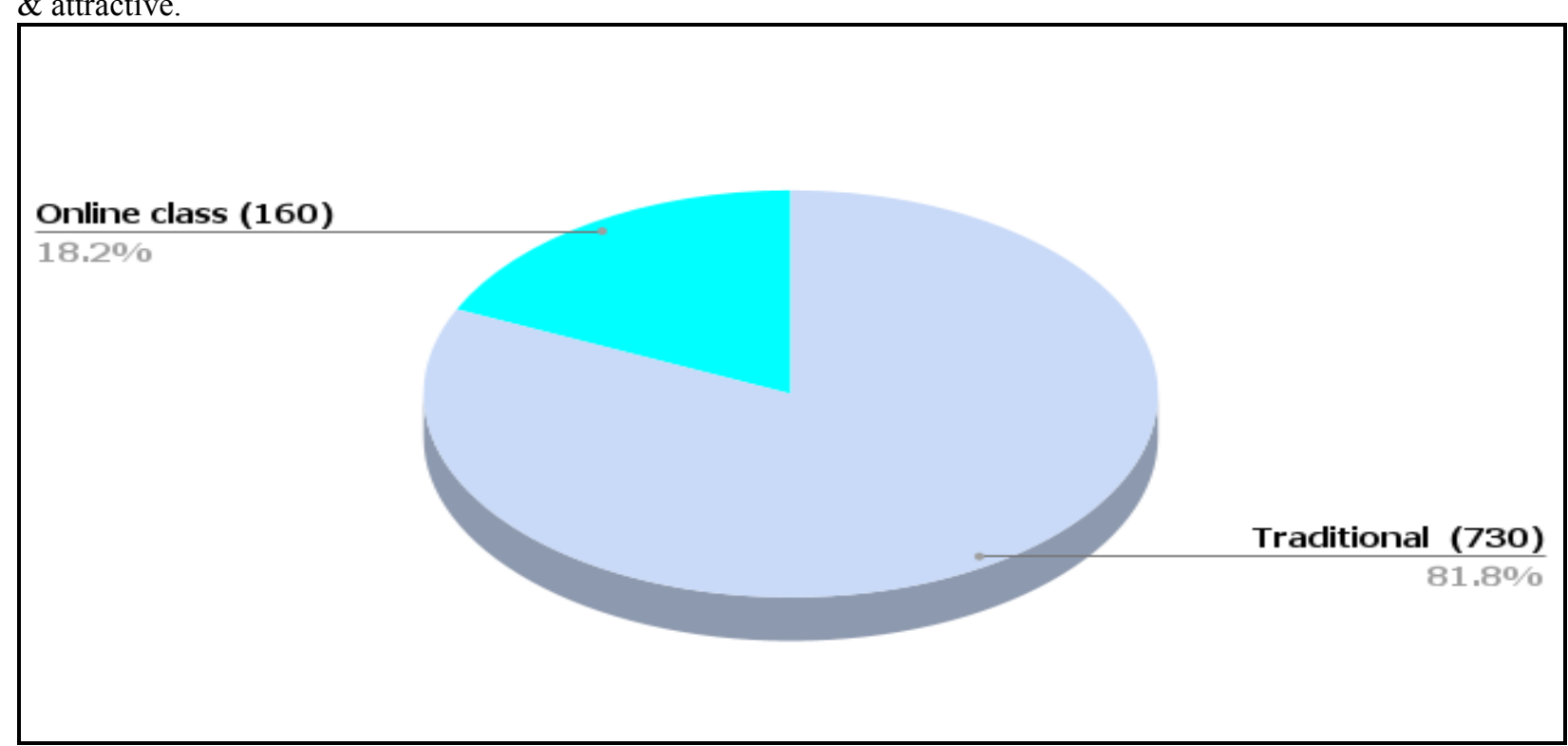

Figure-10: Opinion about innovativeness \& attractiveness of online class

\subsection{Institutional support during pandemic:}

To engage the students more and increase their interest in online classes, several institutional support has been provided by different educational institutions such as providing fees for wireless connectivity, providing gadgets, providing e-mail ID under institutional domain, providing course material through online resources etc. $50 \%$ of the students responded that they have provided the online learning management system facility; $46.3 \%$ get the email Id under institutional domain; $43.8 \%$ can access course materials through online resources and they have also got different online support. 


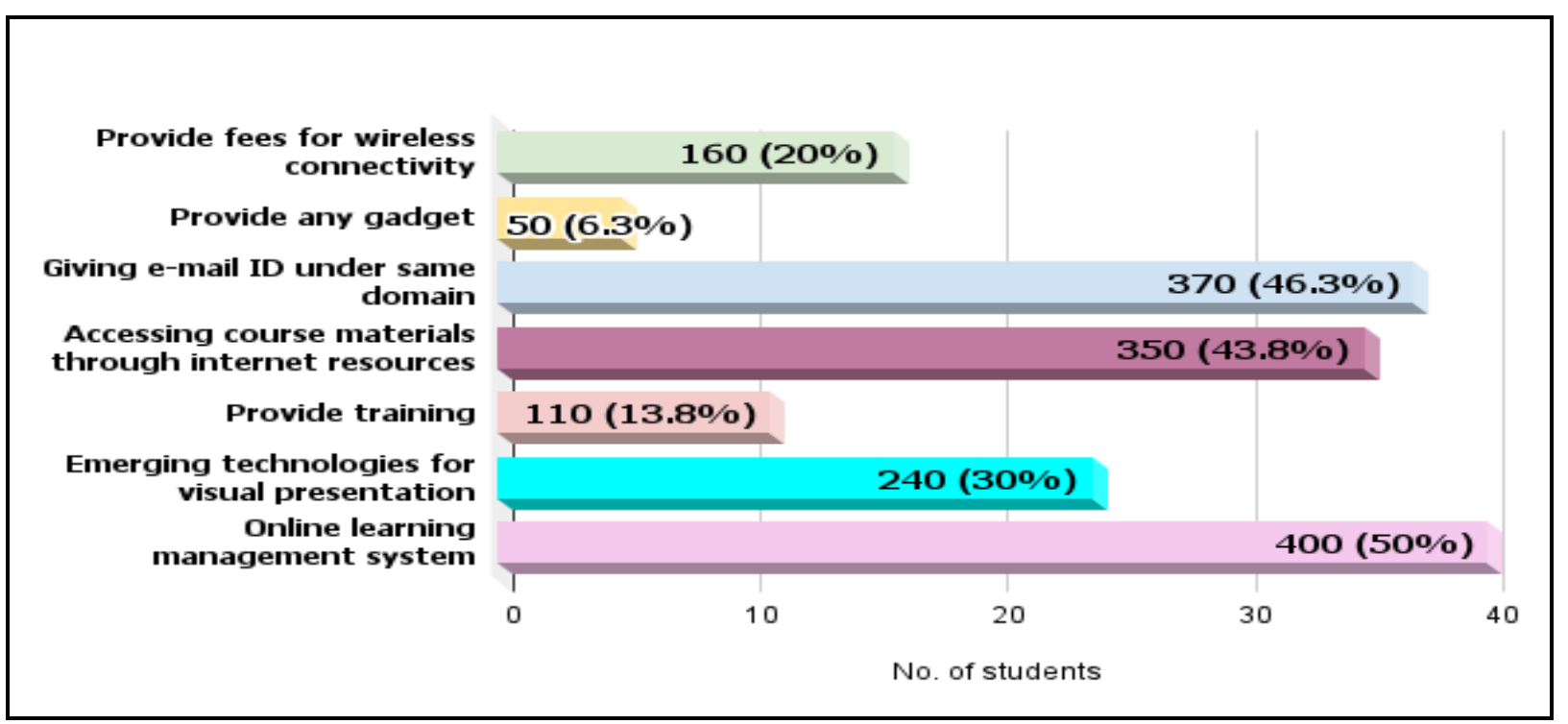

Figure-11: Institutional support during pandemic

5.12 Barriers to be faced during online class:

Although the institutions provide different online support, sometimes students have found different kinds of barriers during online classes. The most common barrier students' face while attending in the online classes is poor connection which is $71.30 \%$. The other barriers are poor motivation $(42.50 \%)$; unreliable technology $(33.80 \%)$; limited timeframe of class $(33.80 \%)$, inappropriate support $(22.50 \%)$; and minimal course design $(17.50 \%)$.

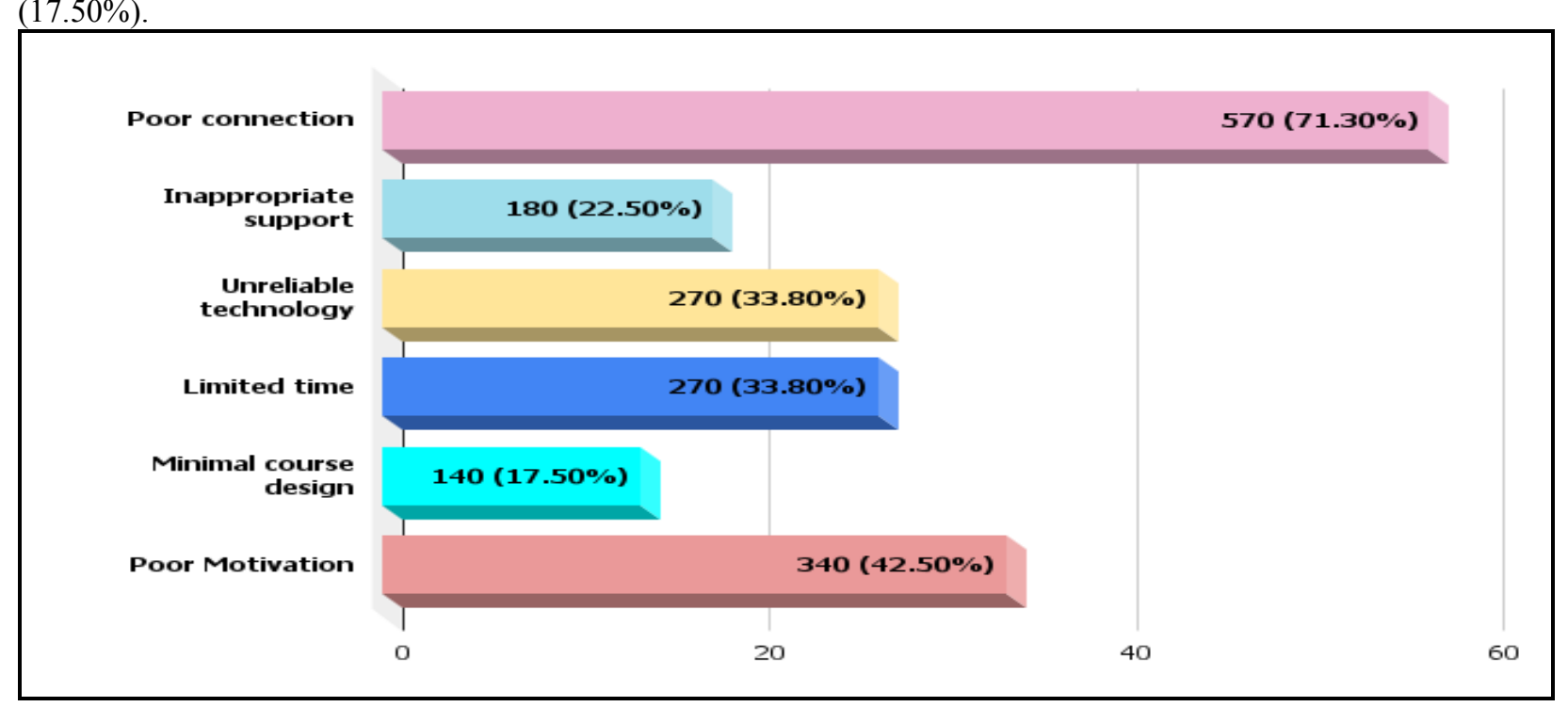

Figure-12: Barriers to be faced during online class

5.13 Benefits enjoyed during online class:

As our students conduct their online classes during pandemic from home, some benefits are enjoyed by them. In our study, it was found that among 890 students $85 \%$ students said that one of the major benefits of online classes is easy to attend class from anywhere. $30 \%$ of students said that the other major benefit of online classes is convenient access to course materials. The students who are introverted prefer online classes and $28.7 \%$ students gave their opinion about this issue. Another $28.7 \%$ students feel that because of online classes they are more connected with faculties than before. 
80

60

$680(85 \%)$

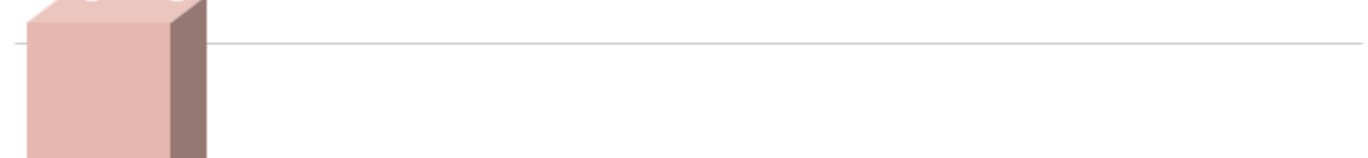

40

20

$230(28.7 \%) 240(30 \%)$

$\mathrm{O}$

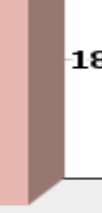

Easy to attend class from anywhere

\section{To develop
real world skills}

)

$180(22.5 \%)$

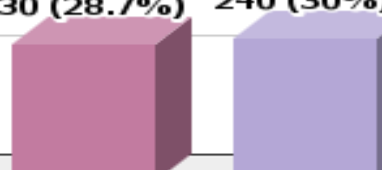

$210(26.3 \%)$

$230(28.7 \%)$

More

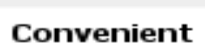

connectivit

with

faculties

to access

course

materials

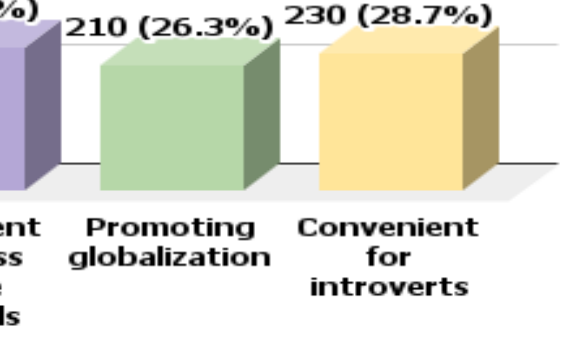

Figure-13: Benefits enjoyed during online class

\subsection{Level of satisfaction regarding online class:}

Our education system collapsed in the very first stage of the corona epidemic. Then begins a new era in education which is online classes. Online classes or class from home is an indispensable part of our new normal life. The major part of 890 respondents means 39.3\% of students are neutral about online class whereas $24.7 \%$ students are satisfied with online class. $19.1 \%$ of students are dissatisfied with online classes.

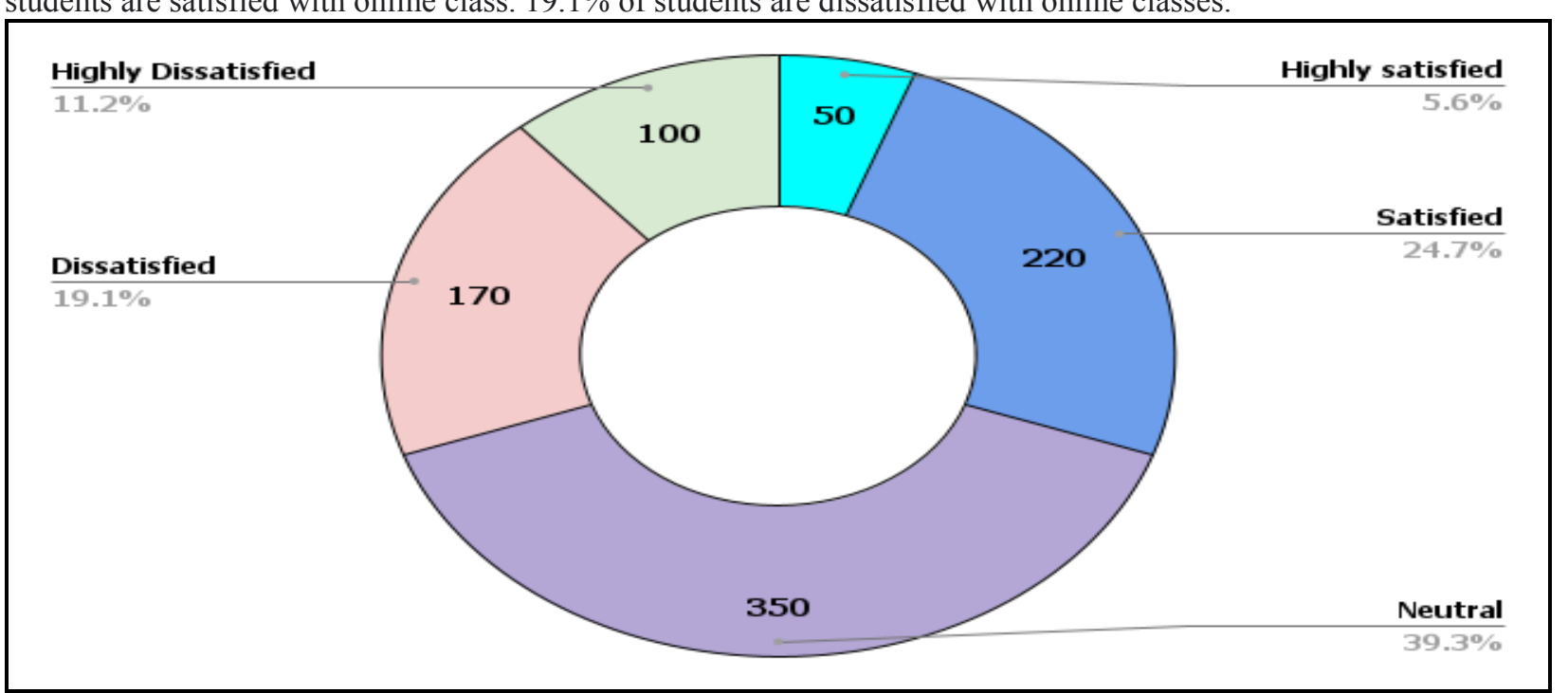

Figure-14: Level of satisfaction regarding online class

\section{Recommendations:}

Private universities conduct online classes from the very beginning in an organized way rather than public universities. After that all the universities started conducting online classes. Some universities have found difficulties in their technology. Technological advancement should be adopted by the educational institutions so that they can easily cope with adverse situations within a very short time. Educational institutions, especially public universities should increase their online support and facilities to motivate students to attend online classes. Although there are a lot of challenges against online classes, all universities must apply it in higher education in a very effective and efficient manner.

Training and development should be provided to the teachers on a regular basis to make the online classes more attractive and innovative. Every higher educational institution should develop software of their own and archive all online classes in their system so that students can easily access the classes later on.

\section{Conclusions:}

During this unexpected COVID-19 lockdown, academic activities have been significantly disrupted and students 
are frustrated with their academic future. However, online classes are the only way to continue studying in the midst of this epidemic situation (Mishra et al., 2020). We have conducted a survey to know the opinion \& perception of graduate $\&$ postgraduate level students at private and public universities in Bangladesh on different aspects of online education. Some students face some challenges in online learning. Students do not have adequate ability to buy mobiles and laptops and most of the students have serious financial problems. Sometimes they can't participate in online classes due to the lack of gadgets, weak signals of the internet and poor wireless internet connection (Demuyakor, 2020; Xue et al., 2020). Internet connection and electricity supply are unstable in rural areas and students have to pay extra money to get internet connection. So, they are very concerned about their current situation (Agung et al. (2020). Rural students are getting less access to the Internet, which is an important reason for less positive perceptions about rural students than urban students (Bisht et al. 2020). Our research reveals the adaptation and perceptions about online education. We think that this study will be helpful for the government and institutional authorities to make academic decisions about more engagement of students on online classes. By using this information, they can plan to continue the online learning process for universities during this pandemic.

\section{References}

1. Agung, A. S. N., Surtikanti, M. W., and Surtikanti, M. W. (2020). Students' Perception of Online Learning during COVID-19 Pandemic: A Case Study on the English Students of STKIP Pamane Talino. Soshum 10 (2), 225-235. doi:10.31940/soshum.v10i2.1316

2. Ahmed, M. Z., Ahmed, O., Aibao, Z., Hanbin, S., Siyu, L., \& Ahmad, A. (2020). Epidemic of COVID-19 in China and associated psychological problems. Asian Journal of Psychiatry, 51, 102092. https://doi.org/10.1016/j.ajp.2020.102092

3. Anwar, S., Nasrullah, M., \& Hosen, M. J. (2020). COVID-19 and Bangladesh: Challenges and how to address them. Frontiers in Public Health, 8. https://doi.org/10.3389/fpubh.2020.00154

4. Assessing the Challenges in Online Class during the Coronavirus (Covid-19) Pandemic in Bangladesh. (2020). www.abacademies.org. https://www.abacademies.org/articles/assessing-the-challenges-in-onlineclass-during-the-coronavirus-covid19-pandemic-in-bangladesh-9885.html

5. Bangladesh Bureau of Educational Information and Statistics (BANBEIS) Ministry of Education. (2018, April). Pocket Book On Bangladesh Education Statistics2017.https://lib.banbeis.gov.bd/BANBEIS_PDF/Pocket\%20Book\%20on\%20Bangladesh\%20Education\%20 Statistics\%202017.pdf

6. Bangladesh IT and digital sector tackling COVID-19 implications. (2020, April 25). LightCastle Partners. https://www.lightcastlebd.com/insights/2020/04/bangladesh-it-and-digital-sector-tackling-covid-19implications

7. Bisht, R. K., Jasola, S., and Bisht, I. P. (2020). Acceptability and Challenges of Online Higher Education in the Era of COVID-19: a Study of Students' Perspective. Asian Education and Development Studies. doi:10.1108/AEDS-05-2020-0119

8. British Council. (n.d.). https://www.britishcouncil.org.bd/en/programmes/education/higher

9. Chen, L., \& Yuan, X. (2020). China's ongoing battle against the coronavirus: Why did the lockdown strategy work well? Socio-Ecological Practice Research, 2(2), 175-180. https://doi.org/10.1007/s42532020-00048-1.

10. Combating the impact of COVID- 19 on public University students through subsidized online class: Evidence from Bangladesh. (2020). Journal of Education and Practice. https://doi.org/10.7176/jep/11-2717

11. COVID-19 educational disruption and response. (2020, March 24). UNESCO. https://en.unesco.org/news/covid-19-educational-disruption-and-response

12. Demuyakor, J. (2020). Coronavirus (COVID-19) and Online Learning in Higher Institutions of Education: A Survey of the Perceptions of Ghanaian International Students in China. Online J. Commun. Media Tech. 10 (3), e202018. doi:10.29333/ojcmt/8286

13. Fami, T., \& Tariq., S. B. (2020, July 28). Is online education system suitable for Bangladesh? The Business Standard. https://www.tbsnews.net/thoughts/online-education-system-suitable-bangladesh-112546

14. Hasan, K., Abdullah, M., Shovon, F., \& Rahman, M. (2020). Shutting down educational institutions under government consideration (n.d.). www.dhakatribune.com. https://www.dhakatribune.com/bangladesh/2020/03/16/shutting-down-educational-Instittons-undergovernment-consideration

15. How are countries addressing the COVID-19 challenges in education? A snapshot of policy measures. (2020, March 24). World Education Blog. https://gemreportunesco.wordpress.com/2020/03/24/how-arecountries-addressing-the-covid-19-challenges-in-education-a-snapshot-of-policy-measures/ 
16. Jebril, N. (2020). World Health Organization declared a pandemic public health menace: A systematic review of the coronavirus disease 2019 "COVID-19". SSRN Electronic Journal. https://doi.org/10.2139/ssrn.3566298

17. Lassoued, Z., Alhendawi, M., \& Bashitialshaaer, R. (2020). An exploratory study of the obstacles for achieving quality in distance learning during the COVID-19 pandemic. Education Sciences, 10(9), 232. https://doi.org/10.3390/educsci10090232

18. Majed, N., Jamal, G.R.A., Kabir, M.R.. Online education: Bangladesh perspective, challenges and way forward. (2020, July 28). The Daily Star. https://www.thedailystar.net/online/news/online-educationbangladesh-perspective-challenges-and-way-forward-1937625

19. Massy, W. F., \& Zemsky, R. (1994). Faculty Discretionary Time. The Journal of Higher Education, 65(1), 1-22. https://doi.org/10.1080/00221546.1994.11778471

20. Mishra, L., Gupta, T., and Shree, A. (2020). Online Teaching-Learning in Higher Education during Lockdown Period of COVID-19 Pandemic. Int. J. Educ. Res. Open 1, 100012. doi:10.1016/j.ijedro.2020.100012

21. Parvej, M. I., Tabassum, M., Mannan, S. E., \& Ahmed, F. (2021). Online education during COVID-19 in Bangladesh: University teachers' perspective. Aquademia, 5(1), ep21005. https://doi.org/10.21601/aquademia/9611

22. Rahman, M., Aziz, M. U., \& Ahmed, S. O.COVID-19 boosts digitization of higher education in Bangladesh. (2020). World Bank Blogs. https://blogs.worldbank.org/endpovertyinsouthasia/covid-19-boosts-digitizationhigher-education-bangladesh

23. Rahman, N. E. (2020, October 13). Online education during COVID-19: Prospects, challenges and way forward. Online education during Covid-19: Prospects, challenges and way forward theindependentbd.com. https://www.theindependentbd.com/post/254623

24. Rogers, E. M. (2003). Diffusion of innovations (5th ed.). Simon \& Schuster.

25. Sahu, P. (2020). Closure of universities due to coronavirus disease 2019 (COVID-19): Impact on education and mental health of students and academic staff. Cureus. https://doi.org/10.7759/cureus.7541

26. Sarker, M. F., Mahmud, R. A., Islam, M. S., \& Islam, M. K. (2019). Use of E-lEarning at higher educational institutions in Bangladesh. Journal of Applied Research in Higher Education, 11(2), $210-223$. https://doi.org/10.1108/jarhe-06-2018-0099

27. Satici, B., Gocet-Tekin, E., Deniz, M. E., \& Satici, S. A. (2020). Adaptation of the fear of COVID-19 scale: Its association with psychological distress and life satisfaction in Turkey. International Journal of Mental Health and Addiction. https://doi.org/10.1007/s11469-020-00294-0

28. United Nations Educational Scientific and Cultural Organization, 2020b. Covid-19 School Closures Around the World Will Hit Girls Hardest. Retrieved 14 June, 2020, from. https://en.unesco.org/news/covid-19school-closures-around-world-will-hit-girls-hardest.

29. Zaman, N.U. Prospects and perils of online education in Bangladesh. (312020, May). New Age | The Most Popular Outspoken English Daily in Bangladesh. https://www.newagebd.net/article/107290/prospects-andperils-of-online-education-in-bangladesh 